See discussions, stats, and author profiles for this publication at: https://www.researchgate.net/publication/301706969

\title{
Property, Control and Separated Human Biomaterials
}

Article in European Journal of Health Law · April 2016

DOI: 10.1163/15718093-12341411

1 author:

A. Neil Maddox

National University of Ireland, Maynooth

13 PUBLICATIONS 3 CITATIONS

SEE PROFILE

Some of the authors of this publication are also working on these related projects:

Project Death and Conception View project 


\section{Property, Control and Separated} Human Biomaterials

Neil Maddox

Lecturer in Law, National University of Ireland, Maynooth, Ireland

Abstract

This article examines the relationship between the existence of control rights and property in separated human biomaterials. Much of the theory as to what constitutes property is examined and it is contended that Article 22 of the Convention on Human

Issues relating to the existence of property and control rights in separated human biomaterials are invariably linked. The development of technology that allows such materials to be utilised in research and artificial reproduction ex vivo has led to a myriad of questions concerning the status of such materials

1 I. Goold, K. Greasley, J. Herring and L. Skene (eds.), Persons, Parts and Property: How Should 
framed so as to resolve the question as to who is entitled to 'property' in the biomaterial once it has been separated from the person. ${ }^{2}$ Of course, invoking 'property' and the property paradigm — of itself — gives little guidance as to precisely which rights are in dispute. ${ }^{3}$ In actuality, two broad categories of rights are at issue in these cases: the right to derive income from the biomaterial and the right to control the biomaterial. ${ }^{4}$ Disputes over income rights have focused on the right to join in the profits of research conducted with the material. The famous case of Moore $v$. Regents of the University of California ${ }^{5}$ is a typical example. That case was framed as a property dispute. The question was whether the source of excised cells, Moore, or the researchers who had developed a valuable cell line with them had 'property' in the material. Of course, had Mr. Moore succeeded in this argument, he would have sought to join in the lucrative profits that the research would generate.

There are other 'property' issues, however, that are not concerned with income rights, i.e., those concerned with controlling the fate of the biomaterial itself. In such cases, we are again concerned with the rights that the source of the material retains in it once it has been separated from the living body. Such issues commonly arise in relation to research, or the storage, destruction and use of gametes or embryos. Much of the case-law concerns biomaterials that have been held to be property 'as a means of permitting remedial action and compensation for damage done, and most recently, in order to permit possession of sperm for the purposes of in vitro fertilisation'. ${ }^{6}$ Property law is

in Human Body Parts', 23 Hofstra L. Rev. (1994) 693; L.B. Andrews, 'My Body, My Property', 16(5) Hastings Center Report (1986) 28-38, R. Rao, 'Property, Privacy, and the Human Body', 8o Buffalo University Law Rev (2000) 359.

2 As there is 'no property' in the human body, some type of separation is necessary before we can talk of 'property' in the biomaterial: J.E. Penner, The Idea of Property in Law (Oxford: ou P, 1997), pp. 105-127; J.W. Harris, 'Who Owns My Body?', 16(1) Oxford Journal of Legal Studies (1996) 55-84; S.R. Munzer, A Theory of Property (Cambridge: Cambridge University Press, 1990), pp. 37-58; M. Quigley, 'Property in Human Biomaterials - Separating Persons and Things?', 32(4) Oxford Journal of Legal Studies (2012) 659-683.

3 D.C. Hubin, 'Human Reproductive Interests: Puzzles at the Periphery of the Property Paradigm', 29 Social Philosophy and Policy (2012) 106-125, at 107.

4 M. Quigley, 'Propertisation and Commercialisation: On Controlling the Uses of Human Biomaterials', 77 Modern Law Review (2014) 677-702.

5793 P 2d 479 (Cal. 1990). Greenberg v. Miami Children's Hospital 244 F.Supp.2d 1064 (S.D. Fla. 2003) and Washington University v. Catalona 437 F.Supp.2d 985 (F.D. Missouri, 2006) are two more recent examples of disputes over income rights in human materials. See also: R. Rao, 'Genes and Spleens: Property, Contract or Privacy Rights in the Human Body?', 35Journal of Law, Medicine and Ethics (2007) 371-382. 
attractive to judges, as it enables a remedy to be provided where otherwise there would be none. It is also a means of providing continuing rights to subsequent owners, as it can confer rights in rem over a thing as well as rights in personam against a person. ${ }^{7}$ Thus, property is useful as it can fill in lacunae in the law. ${ }^{8}$ The temptation then, as Goold and Quigley note, is to engage in 'backwards reasoning' aimed at finding property in order to achieve the 'right result' with little principled justificatory work. ${ }^{9}$

The relationship between property and control lends some support to this view. The existence of control rights has been used to justify a finding of property in these materials. ${ }^{10}$ Conversely, however, property is sometimes used to justify control, i.e. property protects the control of human biomaterials in whom we believe that control ought to vest. ${ }^{11}$ While it may be tempting to think that control rights and property are synonymous, this is not necessarily the case. Control rights do not inevitably lead to property. ${ }^{12}$ This article examines this inconsistent relationship between control rights and property, and finds that it is bedevilled by conceptual uncertainty. Part 1 sets out the various theories which seek to identify what property is; part 2 examines Article 22 of the Convention on Human Rights and Biomedicine, and posits that it does not presuppose property; Part 3 examines the case-law relating to control and property in sperm and embryos from the UK, Australia and the Us; Part 4 concludes.

Property is complex, and may refer to a myriad of entitlements in a particular resource. To conceive of property as a bundle of rights is a useful analytical took, and is often the first legal conception of property encountered by law students. This theory describes property as a series of normative relations between people regarding things, in contrast to relationships between persons

8 L.B. Moses, 'The Problem With Alternatives: The Importance of Property Law in Regulating Excised Human Tissue and In Vitro Human Embryos', in Goold et al., supra note 1,205 .

9 I. Goold and M. Quigley, 'Human Biomaterials: The Case for a Property Approach', in

$10 \quad$ Yearworth v. North Bristol NHS Trust [2009] 3 W.L.R. 118. 
and the things themselves. ${ }^{13}$ The 'bundle of rights' theory combines two influential analyses of property. First, Hohfeld's description of in rem rights as a myriad of liberties, claim-rights, powers and immunities that an owner holds against others. ${ }^{14}$ Then, in his influential essay 'Ownership', Honoré set down the 'standard incidents' of ownership, that are often found in this bundle. ${ }^{15}$ The bundle which emerges is indeed complex, containing a wide variety of legal relationships, not simply rights.

A number of the standard incidents are as follows:

1) The right to possess (right to exclusive physical control, coupled with a claimright to non-interference),

2) The right to use (a claim right to exclusive use which implies a duty on the part of others not to use the thing without permission),

3) The right to the capital, including the power to transfer, alienate and destroy the thing,

4) The right to manage, which is the power to contract with others concerning the various uses of a thing,

5) The right to security,

6) The right to the income. ${ }^{16}$

These rights are can be further categorised into control rights (numbers 1-5 above), and income rights (number 6). ${ }^{17}$ Control, according to Christman, 'refers to the ability on the part of the person to be the final arbiter over what is done with a thing unless this is contracted away'. ${ }^{18}$ These are independent powers of the owner, as they are not dependent on the consent of others. Honoré noted that, on a broad-interpretation, use and management powers

13 J.E. Penner, 'The Bundle of Rights Picture of Property', 43 UCLA Law Rev. (1993) 711.

14 W.N. Hohfeld, Fundamental Legal Conceptions as Applied in Judicial Reasoning: And Other Legal Essays (New Haven, ст: Yale University Press, 1920).

15 A.M. Honoré, 'Ownership', in: A.G. Guest, Oxford Essays in Jurisprudence: a Collaborative Work (London: OUP, 1961), pp. 107-147.

16 There are other, less central incidents, enumerated by Honoré; namely transmissibility, absence of term, prohibition of harmful use and the residuary character of ownership. Of course not all of these are 'rights', ibid., 113 .

17 Harris refers to these rights as 'use and control' rights and I will adopt this method of referring to them throughout the article: J.W. Harris, Property and Justice (Oxford University Press: Oxford, 1996).

18 J. Christman, 'Self-ownership, Equality, and the Structure of Property Rights', 19 Political Theory (1991) 28-46, 29. 
overlap. ${ }^{19}$ On a narrower interpretation, 'use' merely refers to one's right to personal enjoyment of the thing owned, and excludes management and income. The right to use at one's discretion, he noted, is one of the cardinal features of ownership, and the fact that certain limitations are present within the standard incidents (such as the prohibition of harmful use) does not detract from this as they are precisely defined, while the permissible types of use 'constitute an open list'. ${ }^{20}$ Management powers do not concern personal use, but the right to decide how the thing owned shall be used by others. They include powers to license and permit others to make use of the thing, to define the limits of this permission and to contract with regard to such use. ${ }^{21}$

The bundle metaphor does not provide us with the 'core' of property, i.e. a tool to distinguish property from lesser interests, ${ }^{22}$ but may provide a de minimus threshold below which an interest is definitely not property. ${ }^{23}$ In this regard, Honoré notes that:

... the listed incidents are not individually necessary, though they may be together sufficient, conditions for the person of inherence to be designated 'owner' of a particular thing in a given system... [Furthermore]... the use of 'owner' will extend to cases in which not all the listed incidents are present. ${ }^{24}$

Or, as Quigley notes: 'while every stick in the bundle is sometimes referred to as a property right, individual rights are not constitutive of ownership'. ${ }^{25}$ accepted as standard (for tangible property at least), it is difficult to identify any one essential feature common to all types of property. In addition, and

19 Honoré (1961), supra note 15, 116.

$20 \quad$ Ibid. $\quad 31$

$21 \quad$ Ibid. $\quad 32$

22 In the civil law tradition, however, ownership is not defined by reference to its contents: for the position in Scotland see K.G.C. Reid, 'Body Parts and Property', University of

Edinburgh School of Law Research Paper Series, No 2015/25, p 7 .

23 M. Quigley, 'On Controlling the Uses of Human Biomaterials' supra note 4, 69o; A.M. Honoré, 'Property and Ownership: Marginal Comments', in: T. Endicott, J. Getzler and E. Peel (eds.), The Properties of Law: Essays in Honour of Jim Harris (Oxford: OUP, 2006), p. 137 . 
0

entitlement, that any other entitlement is then recognised and protected. ${ }^{26}$ Honoré seems to suggest that some incidents are more important to establishing ownership than others, but that is the extent of the guidance provided. ${ }^{27}$ Furthermore, ownership rhetoric tends towards convincing us that having property in different things equates with having roughly the same set of rights in those things. ${ }^{28}$ That, of course, is not the case.

Professor Harris provides a detailed description of property that more clearly demarcates property rights from non-property rights. ${ }^{29} \mathrm{~A}$ property institution, he states, contains two elements: trespassory rules and the ownership spectrum. ${ }^{30}$ Trespassory rules forbid a certain class of people from making any use of the thing without consent of the 'owner', but they do not elaborate the uses which the owner may make of the thing. ${ }^{31}$ The 'ownership spectrum' is concerned with the set of 'open-ended' relationships that are protected by trespassory rules. ${ }^{32}$ The relationships are open-ended in the sense that it is impossible to concretely list all of them. This is a reflection of the fact that it would be impossible to reduce an ownership interest to the rules that protect it. ${ }^{33}$ These rights must also authorise self-seekingness by their owner, in order to distinguish them from public property. ${ }^{34}$

A variety of ownership interests may be recognised, and transmissibility is only an essential feature of an ownership interest in money. There a higher end and a lower end to the spectrum. At the higher end is 'full blooded ownership' which entails unlimited powers of control and transmission of the resource (unless the exercise of the power infringes some property independent prohibition). At the lower end of the spectrum 'mere property' embraces some open ended set of use privileges over a resource and some open endedse power

26 As noted by J. Wall, 'The Legal Status of Body Parts: a Framework', 31 Oxford Journal of Legal Studies (2011) 783-793.

27 Honoré, supra note $15,113$.

28 Hubin, supra note 3, 107-109.

29 Harris, supra note 2.

30 Ibid.

31 Ibid. In Wall's view, control rights can be protected by two types of trespassory rules: property rules and liability rules in the taxonomy of Calebresi and Melamed: G. Calabresi and A.D. Melamed, 'Property Rules, Liability Rules, and Inalienability: One View of the Cathedral', Harvard Law Review (1972) 1089-1128.

32 Harris, supra note 2.

33 Although property has been characterised as the right to exclude: T. Merrill, 'Property and the Right to Exclude', 77 Nebraska Law Review (1998) 730.

34 J.W. Harris, Property and Justice (Oxford, Clarendon Press, 1996), pp. 5-6, 100-118. 
of control over uses made by others. Harris posits that any purported property rights in the body would be 'mere property' at best. ${ }^{35}$

Article 22 of the Council of Europe's Convention on Human Rights and

When in the course of an intervention any part of a human body is removed, it may be stored and used for a purpose other than that for which it was removed, only if this is done in conformity with appropriate information and consent procedures. ${ }^{36}$

Beyleveld and Brownsword argue, inter alia, that the regime of informed and tissue, and the use to which they are put. The law relating to the former (takings) is protected by recognising a right to bodily integrity and removing any tissue without appropriate consent would clearly infringe such a right. ${ }^{38}$ Rights relating to use and control of body parts after they have been separated

That the source of the excised material retains an interest in it is implicit in the post-removal consent requirements of Article 22. The crucial aspect of Article 22 is that only the source of the material retains some manner of openended relationship to it, not the researcher in possession of it. The uses to which the latter may put the material is not open-ended, as it is fully described by the terms of the consent. In contrast, it is not possible to exhaustively

36 Council of Europe, Convention for the Protection of Human Rights and Dignity of the

Human Being with Regard to the Application of Biology and Medicine: Convention on Human Rights and Biomedicine (DIR/JUR (96(14))) (Strasbourg; Directorate of Legal

D. Beyleveld and R. Brownsword, 'My Body, My Body Parts, My Property?', 8(2) Health Care 
enumerate the range of uses to which the source of the material may consent to, and the power is thus open-ended and akin to rights on Harris's ownership spectrum. This is reflected in the fact that a fresh consent would be required if it was proposed to put the material to a use other than that originally consented to. Beyleveld and Brownsword do not expressly mention 'openendedness', but do note that the rights contemplated under Article 22 'give us control over the post-removal use of our body parts, by granting us not only the right to set the initial bounds of permitted use but also to sanction any deviation from such permitted use. ${ }^{40}$ Furthermore, they distinguish a scenario (based on avoiding religious harm) where certain uses are expressly prohibited, from that pertaining under Article 22. In this scenario, the consent is drafted as a list of prohibited uses. So, the material can be put to any use so long as it is not one of the prohibited uses. As long as this requirement is fulfilled, there is no need for a new consent to every change of use of the material. ${ }^{41}$ Under Article 22, however, every change of use must be subject to a fresh consent, implying that the subject has a protected interest in the excised tissue most easily explained as a property relationship. ${ }^{42}$

Nevertheless, it is not correct to assert that these rights are use and control rights. Use rights in Honorés standard incidents are claim-rights to exclusive use which imply a duty on the part of others not to use the thing without permission. ${ }^{43}$ Article 22 does not protect 'exclusive use' by the source of the material. Rather, it sets out the right to manage, i.e. the power to contract with others concerning the various uses of a thing. ${ }^{44}$ On a broad interpretation of use, use and management powers are one category: one's right to manage a thing comes from your right to use it. ${ }^{45}$ As Harris notes: 'The idea of property comprises the notion that something that pertains to a person is, maybe within drastic limits, his to use as he pleases and therefore his to permit others to use gratuitously or for exchanged favours. ${ }^{46}$ This will not always be the case, however, and there are situations where the right to manage a thing arises independently of the right to exclusive use of it. It is conceivable, in a situation such as happened in the Moore case, that the source of a sample may have no entitlement to possession or exclusive use of excised biomaterial. Yet,

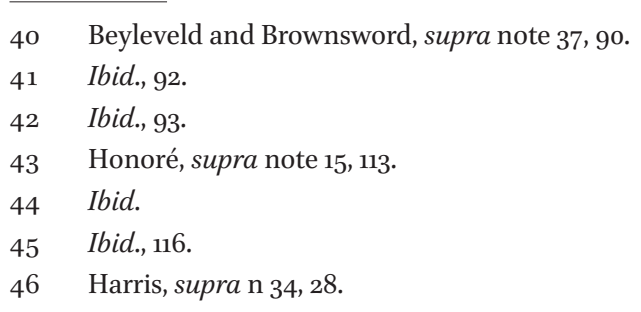


this would not prevent the introduction of a legal requirement that any use of the material be consented to by the source.

In this situation, the rights to manage would clearly be independent of the right to use. As noted, Article 22 allows the source of the biomaterial to initially set the boundaries of permitted use, and to subsequently sanction any deviation from this. This does not imply that these management powers arise from a right to use vesting in the source immediately after the intervention. Indeed, the existence of such rights has proved highly controversial. ${ }^{47}$

If one is to accept this contention that the management powers contemplated by Article 22 are quite separate from any rights of exclusive use that might or might not vest in the source of the material, this undermines the claim that Article 22 presupposes property. As Honoré, and subsequent commentators have stated, though individual incidents may be referred to as property rights, they are not constitutive of ownership. ${ }^{48}$ An individual right, such as the right to manage, is neither necessary nor sufficient for ownership in the absence of other incidents. ${ }^{49}$ To benefit from rights on the ownership spectrum protected in these circumstances does not lead to a conclusion that we are talking about property rights.

The relationship between control and property in human biomaterials has would enable such artificial preservation, the question as to who owned such material ex vivo was of little relevance. It is thus a novel and often troublesome question for judges to unravel. Some commentators believe the existence of control rights should always equate with property, albeit not full-blooded ownership. ${ }^{50}$ At times, this approach is followed and the existence of control

48 Honoré, supra note 23; Quigley, supra note 4, 690.

49 Cf. S. Douglas, 'Property Rights in Human Biomaterials', in: Goold et al., supra note 1, 
other reasoning, is used to justify control over the samples in question. ${ }^{51}$ In the former case, such rights to control may be found in specialised statutes, and it is to these the courts have looked in determining the question of property. ${ }^{52}$

In the United Kingdom, such a specialised statute exists in the form of The Human Fertilisation and Embryology Act 1990 (the HFEA 1990) which regulates the storage and use of gametes and embryos outside of the human body. The act created a detailed statutory framework for the storage of human gametes. Its effect is to greatly restrict the use which may be made of such samples by both the licensed authority and the donors of the samples themselves. Yet, the limited control rights retained by the donor under the act have been deemed sufficient justification to classify the samples as the donor's property. This was the finding in Yearworth v. North Bristol NHS Trust. ${ }^{53}$ The claimants in Yearworth deposited frozen sperm at one of the Defendant's hospitals, licensed under the HFEA 1990. The samples were destroyed and it fell to the court to determine if the sperm constituted 'property' in order to resolve a damages claim for their destruction.

Lord Clarke CJ noted that the men alone generated the sperm by their bodies, ${ }^{54}$ an ambiguous statement that has been considered capable of being construed as 'neo-Lockian in tone [or], alluding to a natural rights view of property'.55 'Ownership', in the judge's view, was 'no more than a convenient global description of different collections of rights held by persons over physical things. ${ }^{6}$ He cited Honoré and noted that not all of these rights need be present for ownership to arise, and that the limitations on use prescribed by the standard incidents of ownership did not detract from its importance as a 'cardinal feature' of ownership'57 The court found that the act preserved the claimant's 'absolute negative control' over the use and continued storage of

53 [2009] 3 W.L.R. 118; C. Hawes, 'Property Interests in Body Parts: Yearworth v. North Bristol NHS Trust 73 Modern Law Review (2010) 119; L. Skene, 'Commentary: Proprietary Interests in Human Body Material: Yearworth, Recent Australian Cases on Stored Semen and Their Implications', 20 Medical Law Review (2012) 227; S. Harmon and G. Laurie, 'Yearworth v. North Bristol NHS Trust: Property, Principles, Precedents and Paradigms', 69 Cambridge Law Journal (2010) 476-493; L.D. Rostill, 'The Ownership that wasn't Meant to Be: Yearworth and Property Rights in Human Tissue', 40 Journal of Medical Ethics (2014) 14-18.

54 [2009] 3 W.L.R. 118, para. 45(f).

55 M. Quigley, 'Property: The Future of Human Tissue', 17 Medical Law Review (2009) 457-466, 461.

$56 \quad$ Supra note 54, para. 28. 
the sperm. ${ }^{58}$ The samples could not be used for the purpose of any treatment without donor's consent. Also, they could require a sample's destruction at any time through the withdrawal of the consent to storage.

Although Yearworth provides a precedent for recognising property rights in the source of human materials, there are limitations. First, the recognition of property rights is confined to use and control rights, and does not extend to income rights. The position in Moore, where the source may be excluded from the income derived from their biomaterials, is distinguishable. ${ }^{59}$ Secondly, having ownership rights over a particular thing does not necessitate a finding of property, and the conceptual foundation of the Court's finding was not made entirely clear. ${ }^{60}$ Harmon and Laurie criticise the shallowness of the discussion of the question of property in the case, and the failure of the court to adequately justify such a conclusion by grounding its finding in much of the legal and bioethical scholarship that has been written on the question. ${ }^{61}$

Notwithstanding these criticisms, the relationship between the men and the samples has many features characteristic of a property institution. Clearly, the statutory restrictions meant they did not enjoy full blooded ownership. In contrast to the position under Article 22 of the Convention on Biomedicine, more than one of Honorés standard incidents is present. The men retained use rights, management rights, and in being able to order the destruction of the sample, retained one feature of the right to capital. In addition to the existence of such rights on the ownership spectrum, there was an element of selfseekingness in that they could consent to the use of the sperm for any reason, or none.

The question as to whether the men had an open-ended set of relationships to the samples in terms of use is more complex. The uses that the samples could be applied for are expressly enumerated by the Act, i.e., the provision of treatment services to the donor and his partner, or to others, or in pursuance of research. It can hardly be said then that the types of use that might have been made by the men of the samples are too exhaustive to enumerate. Nonetheless, the category of persons who may have benefited from the treatment services in the use of the sperm was open-ended, and it this tends to support the conclusion that the men retained property in their samples. While the purposes for which the semen could be used were limited, the manner in which they could be applied for this purpose was not.

6o Harmon and Laurie, supra note 53, 484. 39

61 Ibid., 486. 
0

One of the notable features of this case is that the Court of Appeal did not base its finding of property on the work/skill exception set down in Doodeward v. Spence, ${ }^{62}$ described as a case 'lacking in solid foundation' and 'not entirely logical' in that it could lead to a finding of property in certain excised materials, but not in others, for no good reason. ${ }^{63}$ In basing their findings on the objective fact of control that the men had in the samples, the court attempted to put an end to such inconsistency - a worthwhile goal. Nonetheless, the great difficulty with Yearworth is not the internal logic of the decision, but the fact that an almost identical case was decided without reference to the stored biomaterials being property. Evans v. Amicus Healthcare ${ }^{64}$ was a dispute concerning the fate of embryos under the HFEA 1990. The rights retained in the fertilised embryo by the gamete donors were almost identical to that of gamete donors with the complicating factor that there were two parties who had to consent to the storage and use of the sperm, and either party could withdraw this consent up to the time of implantation. ${ }^{65}$

Both parties clearly had management and use entitlements in the sperm. When one of the parties wished to withdraw his consent, the court was obligated to prefer one of the entitlement holders over the other, favouring the entitlement holder who had elected that the embryo not be used. As Wall notes, however, 'in contrast to Yearworth where management and use entitlements in reproductive material were also litigated, the management and use interests in Evans were recognised and prioritised without treating the fertilised embryo as property'.66 Of course, the detailed statutory scheme contained in the HFEA 1990 provided a method for resolving the dispute between two entitlement holders with conflicting wishes, i.e. Ms Evans' wish to use the embryos for reproduction and her partner's wish that they not be so used. Recourse to the rubric 'property' was thus unnecessary in order to resolve the dispute. ${ }^{67}$ The judgment does not rule out the possibility that the embryos were in fact property. Rather, the court was not called upon to decide the issue.

In the recent Scots case of Holdich v. Lothian Health Board, ${ }^{68}$ the pursuer sought damages for the destruction of irreplaceable sperm. Yearworth was closely examined. Indeed, the defendants argued that the pursuer was trying

$62 \quad[1908]$ H.C.A. 45.

63 Supra note 54 , para. $45(\mathrm{~d})$.

64 [2003] E.W.C.A. Civ. 727.

65 Ibid., para. 165.

66 Wall, supra note 26,7 .

67 HFEA Act 2009, schedule 3.

68 [2013] S.C.S.O.H. 197. 
to 'put a kilt on Yearworth' ${ }^{69}$ Of course, Scots law is significantly different to English law, but the defendants also sought to distinguish Yearworth on its own terms. Lord Stewart's lucid and illuminating decision gives a tepid assessment of the manner in which the Court of Appeal dealt with the property issue in Yearworth. He stated that the Yearworth court derived property from the 'right to use', only one of the eleven incidents of ownership identified by Honoré, and as a result, one need not 'demonstrate ownership in a global sense to be eligible for a Yearworth — type remedy'. ${ }^{70}$ He questioned whether it is appropriate to classify stored sperm as property 'even in a minimalist, Yearworth sense.' ${ }^{71}$ In this regard, the court held that the availability of possessory remedies, such as exist for the burial of corpses, does not necessarily make the objects such remedies property. ${ }^{72}$ Accepting that gametes are sui generis and neither persons or property, the judge noted, is advantageous as it allows personal or property type remedies to be utilised in different contexts, without distorting any doctrinal framework. ${ }^{73}$

The focus of Lord Stewart's opinion on the property question in Holdich is of great interest, as he specifically contemplates that there may an intermediate class of 'things' that are subject to some of the incidents of ownership, but which are not appropriately described as property. Such an approach has merit as the tendency of the non-specialist to conflate full-blooded ownership with lesser forms of ownership, as one of the parties had done in Holdich, ${ }^{74}$ only increases doctrinal confusion. Lord Stewart's approach takes the focus away from whether property exists as a category, and instead examines which remedies are most appropriate in a given factual matrix. The former question was of relevance by necessity in Yearworth so that a remedy would be available to the parties that would not otherwise be. It would inappropriate then to apply this approach to other cases where a finding of property is unimportant to determining the real issues between the parties.

70 Holdich, supra note 68, para. 46. Although, as I have noted above, it is arguable that management rights and one feature of the right to capital are also present.

71 Ibid., para. 47. 
Both gametes and embryos differ from other human tissue in their potential for the creation of human life. They have readily usable genetic information. ${ }^{75}$ Embryos differ from gametes in that they have two progenitors (both of whom will ultimately become genetic parents). An embryo has also been fertilised and there is still ethical and legal debate as to whether it should be characterised as a person, property or in some interim category between these two. ${ }^{76}$

75 R.S. Jansen, 'Sperm and Ova as Property', 11 Journal of Medical Ethics (1985) 123.

76 L.S. Langley and J.W. Blackston, 'Sperm, Egg and a Petri Dish: Unveiling the Underlying Property Issues Surrounding Cryopreserved Embryos', Journal of Legal Medicine (2006) 167-206, 167; J. Berg, 'Owning Persons: The Application of Property Theory to Embryos and Foetuses', 40 Wake Forest Law Review (2005) 159.

77 Davis v. Davis 842 S.W.2d 588 (Ten. 1992).

78 B. Brown, 'Reconciling Property Law with Advances in Reproductive Science', 6 Stanford Law and Policy Review (1994-1995) 73, 75.

79 L.B. Moses, "The problem with Alternatives: The Importance of Property Law in Regulating Excised Human Tissue and In Vitro Human Embryos', in Goold et al., supra note 1, 197.

8 o $\quad$ Ibid.

81 As was the case in Evans v. Amicus Healthcare [2003] E.W.H.C. 2161. See also: Davis v. Davis, 842 S.W.2d 588, 589-92; Kass v. Kass 696 N.E.2d (N.Y. 1998); $A Z$ v. $B Z{ }_{725}$ N.E.2d 1051, 1051-54 (Mass. 2000); JB v. MB, 783 A.2d 707, 709-10 (N.J. 2001); In re Marriage of Witten, 672 N.W.2d 768, 772 (Iowa, 2003). 
a number of American cases on this point. Davis v. Davis, ${ }^{83}$ for instance, described embryos as an 'interim category' between property and persons, but the case was ultimately decided on a balancing of the parties' interests. In Kass v. Kass, ${ }^{84}$ the embryos were described in the agreement to storage as 'property', but this was irrelevant to the decision as it was held that the prior agreement was enforceable and thus determinative of the dispute. Similar outcomes were reached in $J B$ v. $M B,{ }^{85}$ and In re Marriage of Witten. ${ }^{86}$

In York v.Jones ${ }^{87}$ there was a dispute between the progenitors of the embryos and the IVF clinic. The former had moved house and wished their embryos transferred to another clinic. This was not a use provided for in the prior agreement to storage, and the clinic argued that the list of uses in the agreement was exhaustive of the claimants' rights in the embryos. The court disagreed. It held that the agreement created an inference that the clinic fully recognised the couple's property rights in the embryos and were thus a bailee of those embryos. The contract thus limited the clinic's dominion and control over the embryos, but not the claimants' ${ }^{88}$ The finding of property here was used to justify granting the claimants control over the embryos in circumstances not contemplated by the original contract. Thus, property was used to trump the claims of the clinic which was not a progenitor.

The resort to the question of property in this case resolved the question as to who had control of the embryos in the absence of a law governing this question, such as a contractual term or statutory provision. As between progenitors, however, property is of little use in determining who should have control over these materials, and the courts have had to resort to other legal means (enforcement of prior contract, or balancing of parties interests) to resolve these disputes. It is of note that, in none of the cases discussed in this section, was an embryo ordered to be used for reproduction against the wishes of one of the progenitors, even though the legal basis for these decisions differed. ${ }^{89}$ This tends to lend support to the view that property is employed in a pragmatic rather than a principled way by the courts, to justify a result favoured by the judge instead of flowing naturally from property existing in the material in the first place.

$83 \quad$ Supra note $77 . \quad 35$

$\begin{array}{llr}84 & 696 \text { N.E.2d (N.Y. 1998). } & 36 \\ 85 & \text { Supra note 81. } & 35\end{array}$

$\begin{array}{lll}85 & \text { Supra note } 81 . & 37 \\ 86 & \text { Ibid. } & 37\end{array}$

$87 \quad$ Supra note $82 . \quad 38$

88 Ibid., 422-427. 39

89 Langley and Blackston, supra note 77. $\quad 40 \mathrm{X}$ 
o

\subsection{The Relevance of Control when Asserting Proper Rights after the Donor Has Died}

The capacity to freeze sperm and eggs is of use to those who believe that their fertility may be compromised in the future. For instance, those about to undergo radiation treatment or surgery for cancer, or who are engaged in hazardous occupations can avail of the facility to store gametes for future use. If the donors die, the question then arises as to what is to be done with the gametes. In particular, the case-law concerns the fate of frozen sperm when the donor has died. While there is a wide consensus that personal choice in procreation should generally be respected, posthumous reproduction raises novel issues. The interests of the family, for example, in not having another child or sibling, the potential cost, and the interests of the child herself in not being born without a genetic parent are all possible counterweights to reproductive autonomy being respected after death. ${ }^{90}$

Nonetheless, in disputes over the semen of a deceased's sperm the determining issue is who is entitled to control over the samples. Normally, the donors' wishes will be indicated in the standard form completed at the time of providing the samples. Disputes can potentially arise if no directions have been given by the donor as to what might happen to his sample post mortem, or if the directions have not been given in writing or in accordance with statutory requirements. There may also be a dispute between family members and partners/wives as to who has control over the sample. ${ }^{91}$ Posthumous control over frozen embryos raises similar issues. The complicating factor with embryos, of course, is that two persons have provided gametes. If an embryo is used for reproduction, both parties reproduce of necessity. Disputes may arise where the survivor has different preferences as to whether they would like to reproduce to those of the deceased..$^{2}$

The Californian authority of Hecht v. Superior Courts of Los Angeles County, is the earliest notable reported case relation to such matters. ${ }^{93} \mathrm{Hecht}$ was cited with approval in Yearworth, but the court was asked to go a step further in determining if the semen could pass by succession. The frozen sperm was deposited with the clear, express, written intention that it be made use of by

\footnotetext{
$90 \quad$ Robertson, supra note 50.

91 Ibid., 1035.

92 Ibid., 1045.

93 (1993) 20 Cal. Rptr 2d 275. Note, however, the earlier French case of Paraplaix v. CECO, discussed at J.A. Robertson, supra note 50, 1035. See also D.A. Rameden, 'Frozen Semen as Property in Hecht v. Superior Court: One Step Forward: Two Steps Backward', 62 Umkc Law Review (1993) 377.
} 
Hecht for the purposes of reproduction after the death of the donor. This intention was expressed in the sperm bank directive, his will, as well as his suicide note. The California Court of Appeal held that the donor had a limited property right in the sperm and it thus fell into the estate and devolved via the residue clause in the will. ${ }^{94}$

It is important to note that the decedent's intention to devise the semen by will did not directly lead to the finding that the sperm was property. Rather, it was the fact that this intention was clear evidence of a desire to exert continuing control over the sperm after it had left his body, i.e., while he was still alive. The intention of the donor to exert control over samples after they have left the body would appear to be relevant for two possible reasons. First, if one accepts that there is no property in unseparated body parts, the semen becomes res nullius on its separation from the body, and the first to exert ownership over it becomes its owner. ${ }^{95}$ Alternatively, if my sperm is my property I must abandon or transfer/donate my rights to it before another can acquire a superior title. ${ }^{96}$ For instance, in Hecht the Moore case was distinguished on the basis that Moore had no interest in what was done with the tissue samples. In circumstances where Moore had been misled, the validity of this distinction was doubted, correctly in this author's view, by the Yearworth court. ${ }^{97}$ Furthermore, Hecht would appear to be authority, not just for the existence of property in the sperm on the death of the deponent, but also during his lifetime. As Hecht concerned the legitimacy of a disposition in a will, the relevant question was whether the sperm was owned by the deceased immediately prior to his death so that it would form part of the estate. ${ }^{98}$

There are three recent Australian authorities which touch on similar issues. In Bazley v. Wesley Monash IVF Pty Ltd, ${ }^{99}$ the sperm sample had been frozen and stored before the death of the donor, but he had not provided any written consent governing the use of the sperm after his death, as was required by the relevant clinical guidelines. Applying Yearworth, it was held that there had been a gratuitous bailment of the sperm prior to the death. The sample was, 'property' for the purposes of the relevant succession statute vested in

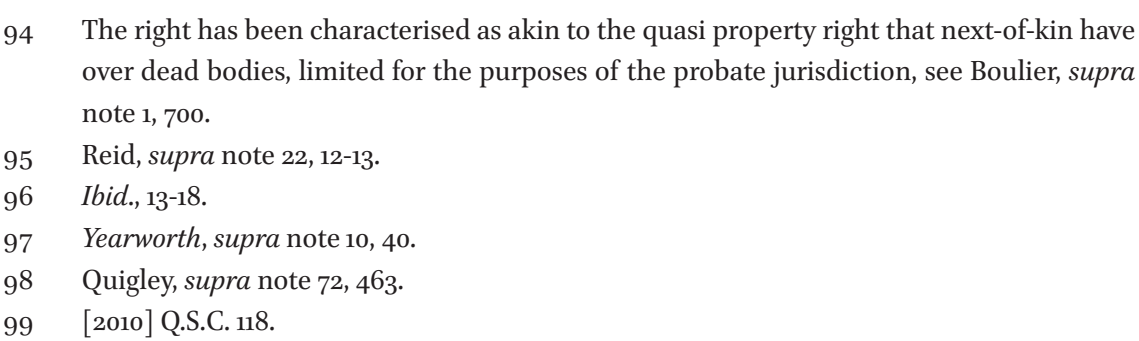


the donor during his life, and his personal representatives after his death. The result is similar to Hecht, and a logical extension of the reasoning in Yearworth.

In both the Estate of the Late Mark Edwards ${ }^{100}$ and Re H, $A E^{101}$ cases, there was a further complicating factor to the dispute in that both decedents had died before the sperm sample had been extracted, and neither had signed the necessary consent forms to such a procedure during their lifetime. In the Edwards case, Mr. Edwards was planning to donate sperm with a view to his wife undergoing IVF with the sample. He died tragically in a workplace accident before the necessary consent forms could be signed, and pursuant to an order made by the duty judge late one evening, sperm was extracted from the body and stored pending the outcome of the case. Hulme J was content to decide the question of property on the authority of Doodeward v. Spence, ${ }^{102}$ and not as flowing from control rights as had been done in Yearworth and Bazley. ${ }^{103}$

As the removal of the tissue did involve such an application of work and skill, the sperm was thus found capable of constituting property. Ms. Edwards was held to be the only person entitled to property in the sperm, as the samples were removed on her behalf, and for her purposes, and 'no-one else in the world had any interest in them.' ${ }^{104}$ Nevertheless, it appears that full-blooded ownership was not contemplated, as it was stated that 'the common law right to possession of preserved samples should continue to be upheld, but full property rights should not be granted.' ${ }^{105}$ Regrettably, the court did not clarify the extent of the rights on the ownership spectrum that were in fact granted. Re $H, A E$ concerned a similar factual matrix, and was decided on similar grounds. ${ }^{106}$ In both of these cases, it seems a finding of property in the samples was necessary so as to provide a remedy to the women. ${ }^{107}$ This was precisely what had happened in Yearworth, and lends support to the view that courts are favouring pragmatic 'case-by-case' application of the property paradigm to such materials.

One might speculate that the divergence of the Australian courts from Yearworth in both Edwards and Re H, AE in applying the Doodeward exception is at least partially based on a certain legal patriotism. It was also done of

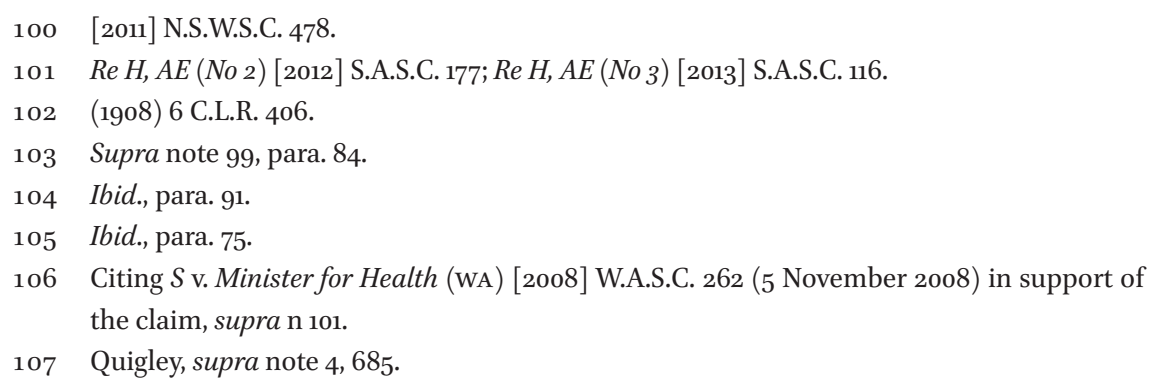


necessity, as the deceased in both cases was not regarded as having property in the samples prior to death. One can infer from this that the control that a person has over their complete body prior to their death is considered differently to the control exercised by the living donors over their frozen samples in Hecht, Yearworth, and Bazley. The latter was deemed sufficient to justify property rights in the samples vesting in the men during their lives that were transmissible via their estate, the former provided no such justification for property. Thus, one might infer from the outcome of these cases that the court does not consider un-separated body parts as capable of being 'owned' and this certainly accords with the rump of the 'no-property' rule surviving and applying to the complete living body.

There is much scholarship on the idea that property must be separate and distinct from the person who owns it. ${ }^{108}$ While we might refer to 'My Body', these assertions are, for the most part, rhetorical and are not intended to imply full-blooded ownership over my complete living body, and would seem to more clearly assert use and control rights, what Harris describes as 'mere property' at best. ${ }^{109}$ Although the philosophical foundations of the separation thesis have been questioned, ${ }^{110}$ Edwards and $H$ do seem to lend tacit support to this view. It is of note, however, that the use and control rights sought by the claimants in these cases, possession of the sample with a view to using them in reproduction, seem to differ little from those that the donor had prior to his death. On their surface, these cases are concerned with recovering possession, use or control of property (Edwards), or seeking damages consequent on its destruction (Yearworth). In substance, however, framing these disputes as property disputes provides a remedial avenue to those who wish to protect their choice to become a genetic parent with a person of their choosing, either by providing them with sufficient rights on the ownership spectrum (use and control) to enable the genetic potential of the samples to be realised, or to compensate if the samples are destroyed and that potential is lost.

These cases also recognise an additional incident on the ownership spectrum - transmissibility. Transmissibility, in Honoré's view, means that the owner may transmit his interest to the holder's successors ad infinitum, although he accepts that transmissibility can exist and 'yet stop short at the first, second or third generation of transmitees.'11 That such limited rights exist in body parts would seem clear from the fact that a person may make

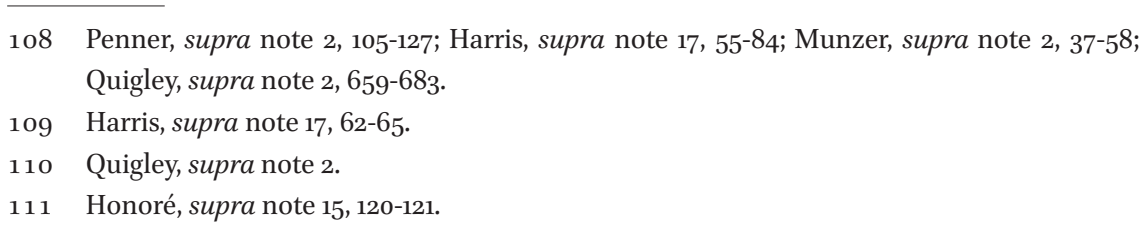


gratuitous donations of their organs after death. The limits, if any, of such a right are not always clear from the case-law. This is an issue of considerable importance. In a case involving an unqualified finding that the sperm was part of the estate of the deceased, the sample would descend to the heirs who presumably would have an unfettered right to use it without regard to the procreative intentions of the deceased. This mischief was foreseen by the French tribunal in Parpalaix, ${ }^{112}$ but has come to pass in other cases. For instance, in Hecht, the decedent has made it very clear that the frozen semen was to be used for reproduction after his death by a specific person. Yet the probate court ordered the sperm to be deposited as residual assets of the estate in a 20:40:40 scheme of arrangement between the girlfriend and two children. Only on appeal did the court revise its view of property as only the property of his girlfriend for the purposes of reproduction. ${ }^{113}$

The clear written directions as to the decedent's posthumous reproductive intentions that were available to the court in Hecht were not available to the judges in the Australian cases. Yet, in each of these cases there were factual circumstances from which one could infer a similar intention. In Bazley, sperm had been deposited prior to death, while in Edwards and Re H, $A E$ there was evidence that decedent had similar intentions. In $R e H, A E$, the use of the sperm was limited to treatment procedures involving the decedent's former partner, a similar qualification to that contained in Hecht. ${ }^{114}$ One might speculate that had the question been put to the court in Edwards, it would have limited the right to use the sperm to the surviving partners of the men. That is not the case, however, and the claimant in Edwards was granted a right of possession seemingly without qualification. ${ }^{115}$

As Hulme J noted 'all that is sought is a declaration that she is entitled to possession of the sperm. The Court is being asked, in effect, to put aside any consideration of what she might do with it as a result of such possession.' ${ }^{116}$ As Hubin has noted, it is tempting to consider that property in different things equates with roughly the same set of rights in those things. ${ }^{117}$ The question as to whether the surviving partners in these cases could sell the samples, or make use of them with a different person is left unanswered. It would seem doubtful that such a result, equating as it does with granting full-blooded

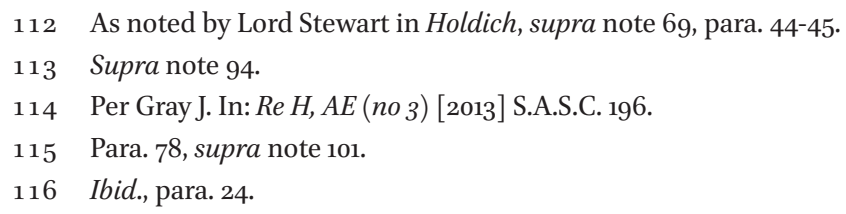


ownership in the samples to the women, would have been intended or desirable in any of these cases. Yet, such is the danger of invoking property as a concept with all of its imprecision as a method of demarcating which rights are in issue. Gametes and embryos are, of course unique because of their potential for reproduction. Although capable of being preserved in a viable state when separated from the body, there is some uneasiness as to whether they are truly separate from the person given their potential to render a donor a genetic parent with all the attendant psychological, and possibly financial consequences of such an occurrence. ${ }^{118}$

The issues of control and property rights in separated human biomaterials are intertwined and often conflated. This are not synonymous issues, however, and the existence of control rights does not inevitably lead to a conclusion that one has property in these materials. While each of Honorés standard incidents are commonly referred to as property rights, individually they are not sufficient for property to exist. Just because an object is subject to some of the incidents of ownership does not always lead to a conclusion that it is property. At the very least, more than one of Honorés standard incidents must be present for there to be property. Article 22 of the Convention on Biomedicine merely provides

The attempt of the Court of Appeal in Yearworth to place its finding of propand there is an inconsistent relationship between control and property. First, absence of Yearworth - type control rights has not prevented courts from finding that property exists, utilising some other justification. Thus, 'property' as a category is still applied in an inconsistent manner for differing and sometimes contradictory purposes. Control rights have been used to justify a finding of property but not any additional control rights in some of the cases (Yearworth, Bazley), while conversely being utilised to justify continuing control in cases where a finding of property has been justified on other grounds (Hecht, Edwards, H, AE, York v. Jones). Such results are undoubtedly related to 
0

remedies where deemed appropriate, while not providing any detailed justificatory grounding for such a finding.

There are additional difficulties. Invoking property as a category gives little indication of itself as to the rights we are talking about since an object may be property when many of the incidents associated with full-blooded ownership are either missing or circumscribed. The absence of a definite criteria for establishing what property is, as well as the tendency to conflate property rights with full blooded ownership further confuses matters, and may lead to unintended consequences as is evident in Hecht and Edwards. Regrettably, in cases where control and property are in issue, courts have tended to put aside questions as to whether separated human biomaterials ought appropriately to be considered objects of property, preferring instead to invoke property in a haphazard manner to provide a remedy where none would otherwise be available, or as a means to justify continuing control of the material by one of the parties to the litigation. Indeed, seeking to categorise objects as property or non-property can be unhelpful in moving the focus of discussions away from what the appropriate remedy should be, to one of taxonomy. Identifying appropriate remedies with precision should surely be the focus of these disputes. The concept of property is not precise, and judges should be cognisant of this deficiency and the difficulties it can lead to when approaching disputes in this area. 